\section{Irrigation Regimes Affect Fruit Soluble Solids Concentration and Rate of Water Loss of 'O'Henry' Peaches}

\author{
Carlos H. Crisosto ${ }^{1}$, R. Scott Johnson ${ }^{2}$, Juvenal G. Luza ${ }^{3}$, and \\ Gayle M. Crisosto ${ }^{3}$ \\ Department of Pomology, University of California, Kearney Agricultural \\ Center, Parlier, CA 93648
}

Additional index words. Prunus persica, cuticle, internal browning, mealiness, water stress, excess irrigation, storage, quality

\begin{abstract}
The effect of irrigation management strategies on the quality and storage performance of 'O'Henry' peaches [Prunus persica (L.) Batsch] was studied for two seasons. The deficit irrigation treatment induced a higher fruit soluble solids concentration and lower fruit weight. The excess irrigation treatment, compared to the optimum treatment, increased the rate of fruit water loss without altering fruit quality and storage performance. Scanning electron microscope observations indicated a higher density of trichomes on fruit from the deficit and optimum irrigation treatments than from the excess irrigation treatment. Light microscopy studies indicated that fruit from deficit and optimum irrigation had a continuous and much thicker cuticle than fruit from the excess irrigation treatment. These differences in exodermis structure may explain the high percentage of water loss from fruit from the excess irrigation treatment compared to the deficit and optimum irrigation treatments.
\end{abstract}

Despite the important role of water in fruit growth and development, few specific studies have reported the influence of the amount and the timing of water applications on peach quality at harvest and postharvest (Claypool, 1977; Kader, 1988).

Veihmeyer and Hendrickson (1949) reported a reduction in yield and fruit size and an increase in soluble solids concentration (SSC) and internal breakdown (IB) (tough, leathery flesh texture) of peaches when trees were allowed to grow on a shallow soil without irrigation water during the growing season. Water stress induced by allowing soil matric potential of a peach orchard to dry down to 0.5 MPa between irrigations resulted in increased fruit SSC compared to the normally irrigated optimum treatment (Uriu et al., 1964).

Irrigation treatments that caused moderate differences in water potential $(<0.1 \mathrm{MPa}$ at predawn) altered wine grape (Vitis vinifera $\mathrm{L}$.) composition at harvest (Matthews and Anderson, 1988). Water deficit treatments increased the concentration of phenolic compounds and

Received for publication 25 Oct. 1993. Accepted for publication 1 June 1994. This study was funded in part by a grant from the California Tree Fruit Agreement and LISA. The mention of commercial products, their source, or their use in connection reported herein is not to be construed as either an actual or implied endorsement of said products. We thank A.A. Kader and F.G. Mitchell for their technical assistance in the internal breakdown evaluation tests. The cost of publishing this paper was defrayed in part by the payment of page charges. Under postal regulations, this paper therefore must be hereby marked advertisement solely to indicate this fact.

${ }^{1}$ Extension Postharvest Physiologist.

${ }^{2}$ Extension Pomologist.

${ }^{3}$ Research Assistant. anthocyanins but decreased malate. High levels of phenolic compounds, which may result from deficit irrigation, have been related to increased incidence of internal browning in stone fruit (Kader, 1988).

In California, during the 1978 and 1979 seasons, a preliminary study to understand the influence of water stress on stone fruit quality was carried out by Beutel and Kader (unpublished data). Their data indicated that peach, nectarine, and plum (Prunus salicina Lindel.) fruit respiration and ethylene production rates were not influenced by preharvest water stress. Fruit from the water stress treatment had a higher SSC than the control.

The possibility of reducing the amount of applied water during the growing season without reducing tree performance has been studied on stone fruit in California (Johnson et al., 1992). Similar studies with promising results have been reported on other fruit crops, such as Proebsting, 1993), pear (Pyrus communis L.) (Brun et al., 1985), and wine grapes (Matthews and Anderson, 1988).

In California, in years of normal rainfall, growers tend to overirrigate peaches during the period of final fruit swell before harvest. However, the recent drought period has forced some growers into deficit irrigation. Since specific effects of these different irrigation apple (Malus domestica Borkh.) (Ebel and

Table 1. Irrigation regimes used for 'O'Henry' peach. regimes on stone fruit quality, $\mathrm{IB}$, and storage performance are unknown, we decided to evaluate the effects of excess and deficit irrigation regimes on fruit quality and postharvest performance of 'O'Henry' peaches.

\section{Materials and Methods}

Plant material and irrigation regime treatments

During the $1986-87$ season, a large weighing lysimeter $(4 \times 2 \times 2 \mathrm{~m})$ was constructed at the Univ. of California, Kearney Agricultural Center, Parlier (Phene et al., 1991). In Spring 1988, two 'O'Henry' peach trees were planted in the lysimeter and 1186 additional trees were planted around the lysimeter. Trees were spaced $1.8 \mathrm{~m}$ apart in $4.9-\mathrm{m}$ rows and trained to a perpendicular "V." The lysimeter was used to measure hourly evapotranspiration (ET) from the two peach trees and soil surface. Irrigation with low-volume microsprinklers in the rest of the field was initiated and controlled by the lysimeter.

For the first 2 years (1988-89), the whole field was irrigated uniformly with $\approx 100 \%$ ET to achieve optimum growth. Beginning in 1990, eight irrigation treatments applying different amounts of water during different phases of fruit growth were imposed with six replications per treatment. Trees under the optimum water $(120 \%$ to $130 \%$ ET) treatment were irrigated as indicated by the lysimeter readings but received $\approx 20 \%$ to $30 \%$ more water than called for because trees were slightly larger and irrigation efficiency was lower. Neutron probe readings were taken every 1 to 2 weeks to assure soil water content levels remained constant during the season. Three irrigation treatments that are normally used by the industry were selected in this experiment (Table 1).

\section{Statistical design and analysis}

The design was a randomized complete block with three irrigation treatments and six replications per treatment. The SAS program (SAS, 1988) was used for analysis of variance. Means were separated using the LSD test at $P \leq$ 0.05 .

\section{Postharvest fruit quality evaluation}

Fruit were picked at commercial maturity in early Aug. 1990 and 1991 as determined by ground color and assessed for fruit size (weight), flesh firmness, SSC, percent red surface, titratable acidity, $\mathrm{pH}$, storage life, and IB. Twenty fruit per replication were used for the fruit quality assessments at harvest. Flesh

\begin{tabular}{lccrrr}
\hline \hline Water & \multicolumn{2}{c}{ Water applied (\% of optimum) } & \multicolumn{2}{c}{ Total (mm) } \\
\cline { 2 - 6 } supplied & 18 Apr.-20 June & 20 June-18 Aug. & 18 Aug.-17 Oct. & 1990 & 1991 \\
\hline Optimum & 100 & 100 & 100 & 846 & 1137 \\
Excess & 100 & 150 & 100 & 1026 & 1313 \\
Deficit & 50 & 75 & 50 & 504 & 645 \\
\hline
\end{tabular}


firmness was measured using a U.C. firmness tester with an 8-mm tip (Western Industrial Supply, San Francisco). Skin from opposite cheeks of each fruit was removed and flesh firmness calculated as an average of two measurements per fruit. A wedge from each fruit was removed and combined to form a composite sample. From this composite sample, juice was extracted with a hand press and filtered through cheesecloth. The SSC of this juice was measured using an American Optical refractometer with automatic temperature compensation. A 6-g sample of the same juice was diluted with $50 \mathrm{ml}$ deionized water; the initial $\mathrm{pH}$ was measured, and the sample was titrated to an end point of 8.2 with $0.1 \mathrm{~N} \mathrm{NaOH}$. Titratable acidity was expressed as percent malic acid.

Storage life. Sixty fruit per replicate were stored in air at $0 \mathrm{C}$ and $90 \%$ relative humidity (RH) [vapor pressure deficit (VPD) $=0.61$ $\mathrm{kPa}$ ]. Twenty fruit each were removed after 2 , 4 , and 6 weeks of storage. Ten fruit were evaluated for flesh firmness and SSC, the other 10 fruit were ripened at $21 \mathrm{C}$ and $60 \% \mathrm{RH}$ $(\mathrm{VPD}=1.8 \mathrm{kPa})$ for 5 to 7 days before examination for IB. The IB symptoms were evaluated in terms of flesh browning by using a scoring system where $1=$ none, $2=$ very slight browning in the pit cavity, $3=$ slight browning in the pit cavity and surrounding flesh tissue, $4=$ moderate browning on $<50 \%$ of the flesh, $5=$ severe browning on $50 \%$ to $75 \%$ of the flesh, and $6=$ extreme browning covering $>75 \%$ of the flesh. Texture was rated as juicy, mealy, or hard. These observations were made on the mesocarp after the fruit were cut transversely along the plane of the suture. A treatment was commercially unacceptable when $>15 \%$ of the fruit showed flesh browning (higher than score 3 ) or $>25 \%$ of the fruit were mealy (Nanos and Mitchell, 1991).

Fruit water loss susceptibility. Groups of five uniform-size fruit per replicate were weighed and placed in a temperaturecontrolled room at $25 \mathrm{C}$ and $30 \% \mathrm{RH}(\mathrm{VPD}=$ $1.26 \mathrm{kPa}$ ). In 1990, fruit were reweighed after $24 \mathrm{~h}$; in 1991, fruit were reweighed daily for 4 days. Weight loss was calculated as the percent reduction from the original weight.

Fruit epidermis and cuticle studies. During 1991, three uniform-size peaches from each replication were collected at commercial maturity (based on ground color) and handled for fruit anatomical observations according to Luza et al. (1992). Samples for scanning electron and light microscopy studies were prepared by cutting $4 \mathrm{~mm}^{2} \times 2$-mm-thick pieces from the midcheek area of the fruit. After this, samples were fixed in a $4 \%$ glutaraldehyde solution containing $0.2 \mathrm{M}$ dipotassium phosphate (buffer) and $0.1 \mathrm{M}$ citric acid monohydrate, $\mathrm{pH} 7.0$, and subjected to a mild vacuum for $30 \mathrm{~min}$.

Scanning electron microscopy (SEM). Samples for SEM were dehydrated through an ethanol series, except that the $100 \%$ ethanol was replaced with amylacetate. The samples were critical-point-dried with $\mathrm{CO}_{2}$, mounted on stubs with silver paint, and then sputtercoated with 40 to $50 \mathrm{~nm}$ of gold. Photographs and observations were made on an ISI DS-130 scanning electron microscope (International Scientific Instruments, Santa Clara, Calif.) operated at $10 \mathrm{kV}$.

Light microscopy. Samples were washed in the buffer noted above at room temperature, dehydrated through an ethanol series, and infiltrated with glycol methacrylate resin (DuPont-Sorvall, Wilmington, Del.). Sections were cut at $5 \mu \mathrm{m}$ using glass knives on a Sorvall JB4 microtome (DuPont-Sorvall). To analyze general cellular structure, sections were stained with $0.5 \%$ toluidine blue in $0.15 \mathrm{M}$ $\mathrm{K}_{2} \mathrm{PO}_{4}$ and $0.5 \%$ safranin in $0.2 \mathrm{M}$ Tris- $\mathrm{HCl}$ and counterstained with calcofluor white MR2 (American Cyanamide Co., Bond Brook, N.J.). For cuticle observations, slides were stained with sudan black in $100 \%$ acetone and mounted in glycerol. Photomicrographs were taken using Kodak Pan-X film for bright field and Kodak Tri-X for fluorescent images.

\section{Results and Discussion}

\section{Fruit quality}

Flesh firmness, percent red surface, acidity, and $\mathrm{pH}$ had not been altered at harvest by the irrigation regimes in either 1990 or 1991. Average fruit size, measured as fruit weight, was lower, but SSC was higher for fruit from the deficit irrigation treatment than from the optimum or excess irrigation treatments (Table 2 ). Peaches or nectarines with $11 \%$ SSC are highly accepted by consumers (Claypool, 1977). Thus, although fruit from the deficit irrigation treatment were smaller, they probably would be preferred by consumers over fruit from the other treatments. An economic study by Parker et al. (1991) showed that peaches with a higher SSC have a higher retail value.

\section{Storage life}

Irrigation treatments did not influence the incidence of IB or flesh mealiness after 2, 4, and 6 weeks in storage (data not shown). For both seasons, mealiness was more prevalent than flesh browning, and fruit were commercially unacceptable due to excessive (severe) IB after 4 weeks of storage. In 1990, 13\% and $56 \%$ of the fruit were mealy by week 4 and 6 , respectively, while $21 \%$ and $35 \%$ of the fruit were mealy by week 4 and 6 in 1991 . The results suggest a postharvest life of $\approx 4$ to 5 weeks for 'O'Henry', which agrees with the findings of Nanos and Mitchell (1991).

\section{Fruit water loss}

Fruit water loss from deficit irrigation was lower than from excess or optimum irrigation (data not shown). Fruit from the excess irrigation had lost nearly $35 \%$ more water than fruit from deficit or optimum irrigation after $24 \mathrm{~h}$. During 1991, shriveling symptoms were visible when weight loss exceeded $10 \%$ of the initial fresh weight. The symptoms occurred within $47 \mathrm{~h}$ on fruit from the excess irrigation,
Table 2. Effect of three irrigation regimes on fruit weight and soluble solids concentration (SSC) of 'O'Henry' peach at harvest.

\begin{tabular}{lcc}
\hline \hline Water & $\begin{array}{c}\text { Fruit } \\
\text { wt } \\
(\mathrm{g})\end{array}$ & $\begin{array}{r}\text { SSC } \\
(\%)\end{array}$ \\
supplied & 1990 & \\
& $218 \mathrm{a}^{\mathrm{z}}$ & $11.7 \mathrm{a}$ \\
Optimum & $221 \mathrm{a}$ & $10.8 \mathrm{a}$ \\
Excess & $192 \mathrm{~b}$ & $13.3 \mathrm{~b}$ \\
Deficit & 1991 & \\
& $291 \mathrm{a}$ & $10.7 \mathrm{a}$ \\
Optimum & $304 \mathrm{a}$ & $10.9 \mathrm{a}$ \\
Excess & $244 \mathrm{~b}$ & $11.2 \mathrm{~b}$ \\
Deficit &
\end{tabular}

${ }^{\mathrm{z}}$ Mean separation within columns and year by LSD test at $P \leq 0.05$.

within $57 \mathrm{~h}$ on fruit from the optimum treatment, and within $64 \mathrm{~h}$ on fruit from deficit irrigation (Fig. 1). Our water loss susceptibility test exposed fruit to a very high VPD, which induced an extremely high rate of water loss, $\approx 36$ times higher than fruit would normally experience during storage (0C, $95 \%$ $\mathrm{RH}, 0.61 \mathrm{kPa}$ ). Under commercial handling conditions, the difference among treatments in appearance of the first noticeable shrivel symptoms may take much longer and would become commercially important for long-term storage or during retail handling.

\section{Fruit epidermal and cuticle structure}

SEM observations revealed no differences in the fruit surface among the three treatments, except that fewer trichomes were present on the fruit from the excess irrigation (Fig. 2E) treatment compared to the optimum (Fig. 2C) or deficit (Fig. 2A) treatments. Wax deposition on the surface formed typical ridging for the cultivar, as previously described by Fogle and Faust (1975). The thinner cuticle (Fig. 2F) and a lower density of trichomes (Fig. 2E) in fruit from the excess irrigation treatment would be responsible for a reduced boundary layer resistance and thus increase the rate of water loss.

Fruit tissue morphology was not altered by the irrigation treatments (Fig. 2). All of the fruit from the optimum irrigation treatment showed a normal cuticle and an exodermis composed of two to four layers of epidermal cells with trichomes and one to two layers of hypodermis cells (Fig. $2 \mathrm{C}$ and D). Large mesocarp cells were located underneath the exodermis.

Fruit from the deficit irrigation treatment (Fig. 2B) showed a thicker cuticle than fruit from the other two treatments (Fig. 2D and F). Fruit from the optimum treatment had some samples with a thin cuticle and some with a thick cuticle. Within the same fruit, a combination of areas with thin cuticle and areas with thick cuticle was observed. Because the epicuticular waxes and cuticle act as partial barriers to water vapor movement from fruit to environment (Nobel, 1983), differences in the fruit water loss potential related well with the anatomical differences in cuticle and epicuticular waxes induced by the different irrigation treatments. 


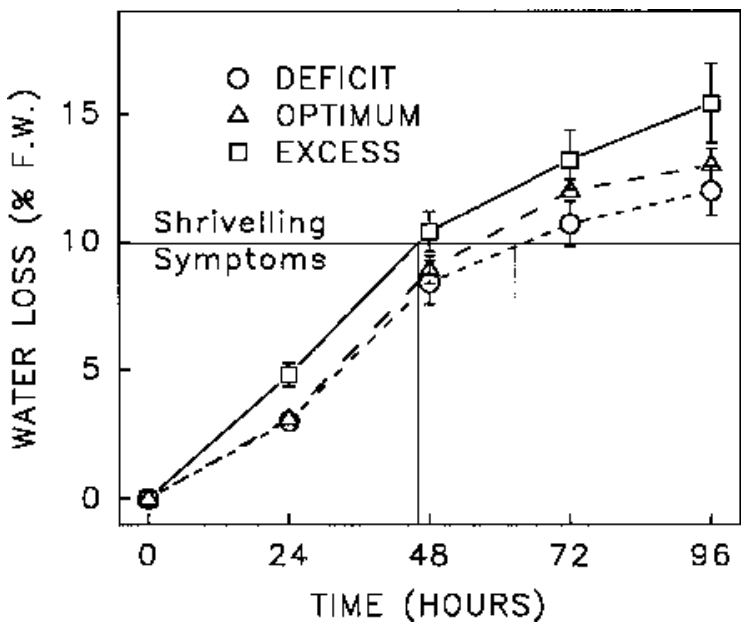

Fig. 1. Relationship between water loss (percentage of initial fresh weight at vapor pressure deficit of 1.26 $\mathrm{kPa}$ ) and time after harvest (hours) for 'O'Henry' peaches grown under three irrigation treatments: $(\mathrm{O})$ deficit, $(\Delta)$ optimum, and $(\square)$ excess. Values represent an average of six replications for the 1991 season. Bars indicate standard errors.

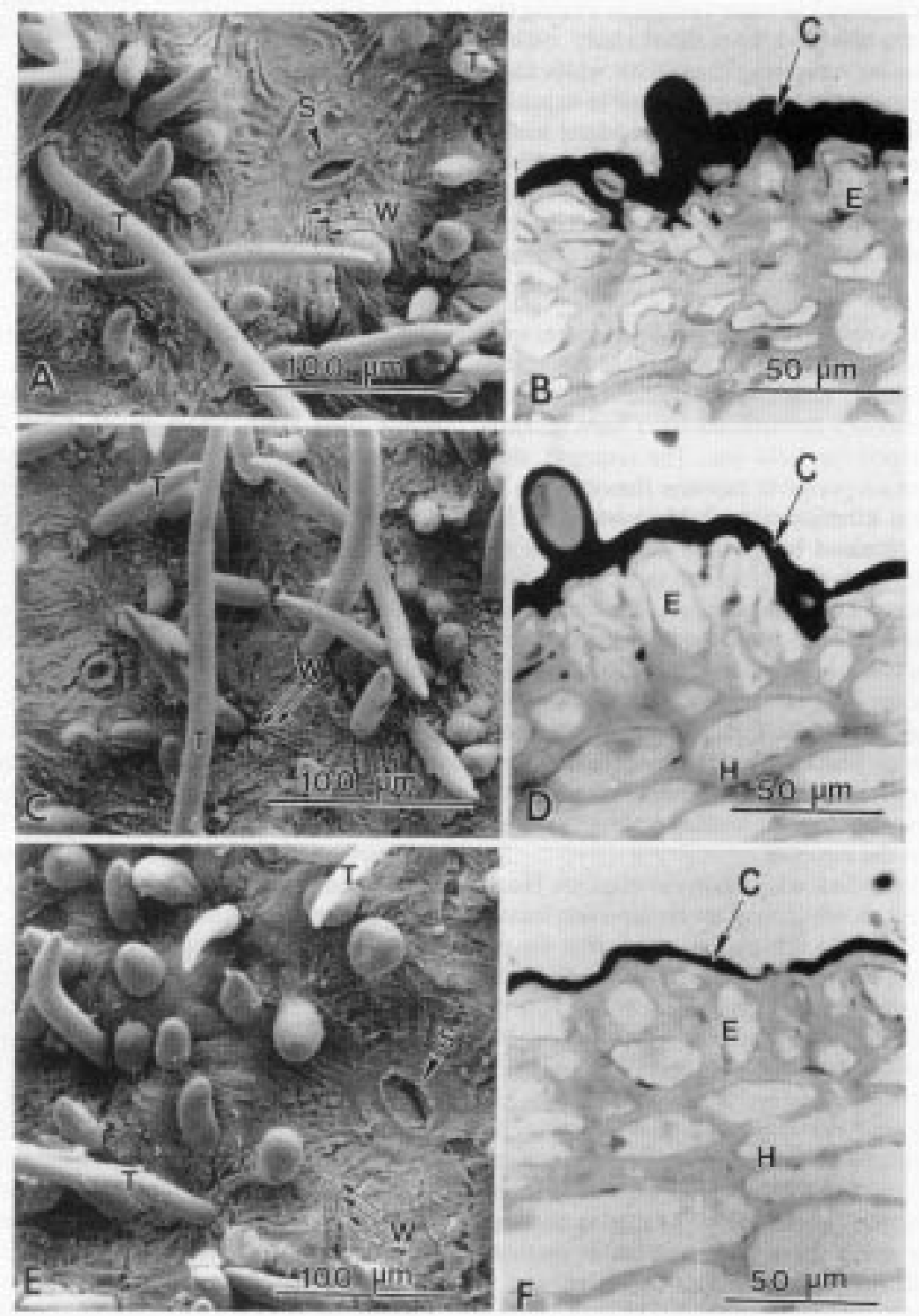

Fig. 2. Scanning electron microscopy (SEM) and light microscopy (LM) observations following harvest of 'O'Henry' peach fruit grown under three controlled water deficit irrigation treatments. (A, B) deficit; $(\mathbf{C}, \mathbf{D})$ optimum; (E, F) excess. A, C, E via SEM; B, D, F via LM, sudan black stain. $\mathrm{W}=$ wax; T = trichome; $\mathrm{S}=$ stomate $; \mathrm{C}=$ cuticle $; \mathrm{E}=$ epidermis; $\mathrm{H}=$ hypodermis.
In conclusion, the excess irrigation treatment did not alter fruit quality and storage life of 'O'Henry' peach, but its effect on cuticle modification could make the fruit more susceptible to water loss and, possibly, increase disease incidence during commercial storage. Benefits from the deficit irrigation, relative to optimum or excess irrigation, include an increase in SSC, a thicker cuticle, and reduction in the fruit's water loss potential. However, the reduced fruit size and higher SSC relative to consumer acceptance will have to be evaluated economically according to prevailing market conditions before a final recommendation can be made.

\section{Literature Cited}

Brun, C., J.T. Raese, and E. Stahly. 1985. Seasonal response of 'Anjou' pear trees to different irrigation regimes: I. Soil moisture, water relations, tree and fruit growth. J. Amer. Soc. Hort. Sci. 110:830-834.

Claypool, L.L. 1977. Plant nutrition and deciduous fruit crop quality. HortScience 10:45-47.

Ebel, R.C. and E.L. Proebsting. 1993. Regulated deficit irrigation may alter apple maturity, quality, and storage life. HortScience 28:141-143.

Fogle, H.W. and M. Faust. 1975. Ultrastructure of nectarine fruit surface. J. Amer. Soc. Hort. Sci. 100:74-77.

Johnson, R.S., D.F. Handley, and T.M. DeJong. 1992. Long-term response of early maturing peach trees to postharvest water deficit. J. Amer. Soc. Hort. Sci. 117:881-886.

Kader, A.A. 1988. Influence of preharvest factors and postharvest environment on nutrition composition of fruits and vegetables, p. 18-22. In: B. Quebedeaux and F.A. Bliss (eds.). Horticulture and human health-Contributions of fruits and vegetables. Prentice-Hall, Englewood Cliffs, N.J.

Luza, J.G., R. Van Gorsel, V.S. Polito, and A.A. Kader. 1992. Chilling injury in peaches: A cytochemical and ultra-structural cell wall study. J. Amer. Soc. Hort. Sci. 117:114-118.

Matthews, M.A. and M. Anderson. 1988. Fruit ripening in Vitis vinifera L.: Responses to seasonal water deficits. Amer. J. Enol. Viticult. 39:313-320.

Nanos, G. and F.G. Mitchell. 1991. High-temperature conditioning to delay internal breakdown development in peaches and nectarines. HortScience 26:882-885.

Nobel, P.S. 1983. Biophysical plant physiology and ecology. W.H. Freeman and Co., San Francisco.

Parker, D., D. Ziberman, and K. Moulton. 1991. How quality relates to price in California fresh peaches. Calif. Agr. 45(2):14-16.

Phene, C.J., G.J.Hoffman, T.A. Howell, D.A.Clark, R.H. Head, R.S. Johnson, and L.E. Williams. 1991. Automated lysimeter for irrigation and drainage control. Lysimeters for evapotranspiration and environmental measurements. Irr. Div. Amer. Soc. Civil Eng., Honolulu, 23-25 July 1991.

SAS Institute. 1985. SAS user's guide: Basics. 1985 ed. SAS Inst., Cary, N.C.

Uriu, K., P.G. Wereniels, A. Retan, and D. Fox. 1964. Cling peach irrigation. Calif. Agr. 18(7):10-11.

Veihmeyer, F.J. and A.H. Hendrickson. 1949. The application of some basic concepts of soil moisture to orchard irrigation. Proc. Wash. State Hort. Assn. 45:25-41. 